\title{
Use of Neglected and Underutilized Crop Species (NUCS) in some farming communities in the Upper Afram and Upper Dayi River Basins in Ghana
}

\author{
F. Baa-Poku ${ }^{1}$ and I. K. Asante ${ }^{2}$ \\ 1. Department of Environmental Management and Technology, Koforidua Technical University. \\ P. O. Box KF 981 Koforidua, Eastern Region, Ghana. \\ 2. Department of Plant and Environmental Biology, University of Ghana. \\ *Corresponding author's email: frimpomabbp@gmail.com
}

\begin{abstract}
The study examined Neglected and Underutilized Crop Species (NUCS) in two agro-ecologically diverse zones in Ghana with the view to highlighting the varieties, their important benefits and uses among rural households in the Upper Afram and Upper Dayi basins. Qualitative data was gathered from two hundred and seventy-one (271) respondents in six farming communities within the middle belt of Ghana through focused group discussions, interviews and questionnaires. A total of one hundred and twelve (112) NUCS were identified during the study. The diversity of NUCS in the study areas provide an indication of the existence of a valuable plant resource that can be exploited to help address food inadequacy challenges among rural households within the Upper Afram and Upper Dayi basins. Apart from their use as food, medicine, dyes, soap making, fuel wood and livestock feed, some NUCS found within the study basins play very important roles in the cultural practices and traditional ceremonies. These findings demonstrate the untapped potential of NUCS in addressing food and nutritional insecurity among rural households in the country. Institution of regular NUCS focused food fairs at the local (village), district and regional levels to promote local dishes prepared from the indigenous food crops; as well as increased NUCS related research are recommended.
\end{abstract}

Keywords: Ghana; Neglected and Underutilized Crop Species; Diversity; Uses; Upper Afram and Upper Dayi River Basins

Citation: F. Baa-Poku and I. K. Asante. Use of Neglected and Underutilized Crop Species (NUCS) in some farming communities in the Upper Afram and Upper Dayi River Basins in Ghana, 2020; 5(2): $48-63$.

Received: April 3, 2020

Accepted: June 30, 2020 


\subsection{Introduction}

Neglected and Underutilized Crop Species (NUCS) have been conceptualized differently by various researchers and experts. Establishing a universal definition for NUCS has therefore been difficult. In spite of the lack of uniformity in defining Neglected and Underutilized Crop Species (NUCS), some attempts have been made to define them. This study adopts Azam-Ali (2010) conceptual definition which describes NUCS as crops that have hitherto not been categorized as major crops; have not had much research carried out on them; are not being used in a major way at present and are largely restricted to smallholder farming areas. Neglected and Underutilized Crop Species constitute an important component of agrobiodiversity. NUCS occur widely in both temperate and tropical regions including Sub-Saharan Africa, Latin America, and South and East Asia (Padulosi et al., 2013). Increased use of NUCS as source of food and medicine has been reported in Asia and the Pacific particularly in countries such as Malaysia, Nepal, India and the Philippines. In Sub Saharan Africa, the cultivation and use of NUCS is common in countries such as Malawi, Nigeria, Cote d' Ivoire, Uganda, and Zimbabwe (Padulosi et al., 2013; FAO, 2010). Among the categories of food crops that NUCS can be found or belong to include legumes, roots and tubers, fruits, vegetables, nuts, cereals, pseudocereals, oilseeds, aromatic and medicinal plants (Padulosi et al., 2004, 2008). Examples of NUCS found in Sub Saharan Africa include Amaranthus species (Laker, 2007), wild mustard (Brassica spp.) and other wild edible leafy vegetables (Modi et al., 2006). Others include taro (Colocasia esculenta), sweet potatoes (Ipomoea batata), bambara groundnut (Vigna subterranea) and wild melon (Curcubita spp). In Ghana, Aboagye et al. (2010) note that there is diversity of NUCS that can be useful in plant breeding programmes, including Vigna reticulate, wild yam, wild oil palm, and most medicinal plants such as mahogany (Khaya senegalensis) and Rauwolfia vomitoria. NUCS possess several useful and beneficial traits that make them important to the environment and human livelihood. Even though the cultivation of NUCS often produce lower yields compared to the major staple crops, they are relatively more resistant to biotic challenges and are therefore able to adapt to harsh climatic conditions such as poor soils and drought (Padulosi et al., 2013). Environmental concerns such as land use changes; the impact of climate change; and the degradation of land and water resources among others have led to a growing interest in NUCS (IPGR, 2002). Their ability to thrive under harsh climatic conditions makes them valuable and key in the fight against the negative impact of climate change on agricultural food production (Bala Ravi et al., 2006). NUCS also offer good alternative in the event of failure of the main staple crops to survive under such harsh conditions (Mabhaudhi, et al., 2011). Apart from their medicinal value, some NUCS also contain high levels of vitamin $\mathrm{B}_{2}$, and vitamin $\mathrm{C}$ and proteins which are used as substitutes to conventional vegetables in human diet (Mengistu \& Hager, 2008). Neglected and Underutilized Crop Species (NUCS) historically have contributed to ensuring household food security among indigenous communities while creating income generating opportunities for small holder farmers as well (Mabhaudhi et al., 2011). Several studies including Muhammad (2014), Sprent et al. (2009), Bhattacharjee (2009) among others have all pointed to the important benefits of NUCS and their role in contributing to the achievement of food security. Past research studies including Aboagye et al. (2007), Nyadanu \& Lowor (2014), Nyadanu et al., (2015), Nyadanu et al. (2014; 2014b), and Nyadanu \& Aboagye (2014) have all explored various aspects of NUCS in Ghana but there seems to be inadequate investigation into the level of patronage, varieties and uses of these crops among farming communities in major food producing areas in the country. The main objective of this study therefore was to i) inventorize and profile NUCS within the two agro ecological zones within the Upper Afram and Dayi Basins; and also, ii) highlight their uses and benefits. Findings of this research will enhance the limited literature on the inventory of the varieties of NUCS and further enrich indigenous knowledge on the uses and benefits of these often marginalized indigenous food crops within the middle belt of Ghana. 


\subsection{Methods}

\section{$2.1 \quad$ Study Area}

The study was conducted in two river basins, the Upper Afram and Upper Dayi basins both located within the Middle belt of Ghana. The Upper Afram basin area falls within the Forest Savannah Transition Zone in the middle portion of Brong Ahafo region, the northern part of both Ashanti and Eastern regions and the western part of Volta region. The Upper Dayi basin on the other hand lies within the Semi-Deciduous Rainforest of Ghana. The Upper Afram and Upper Dayi basins constitute the major food basket of the nation and therefore are under high influence of market forces due to the large agricultural markets. The two basins are known to possess relatively rich agrodiversity with high levels of rainfall often accounting for the wide variety of food crops and plant species in the areas.

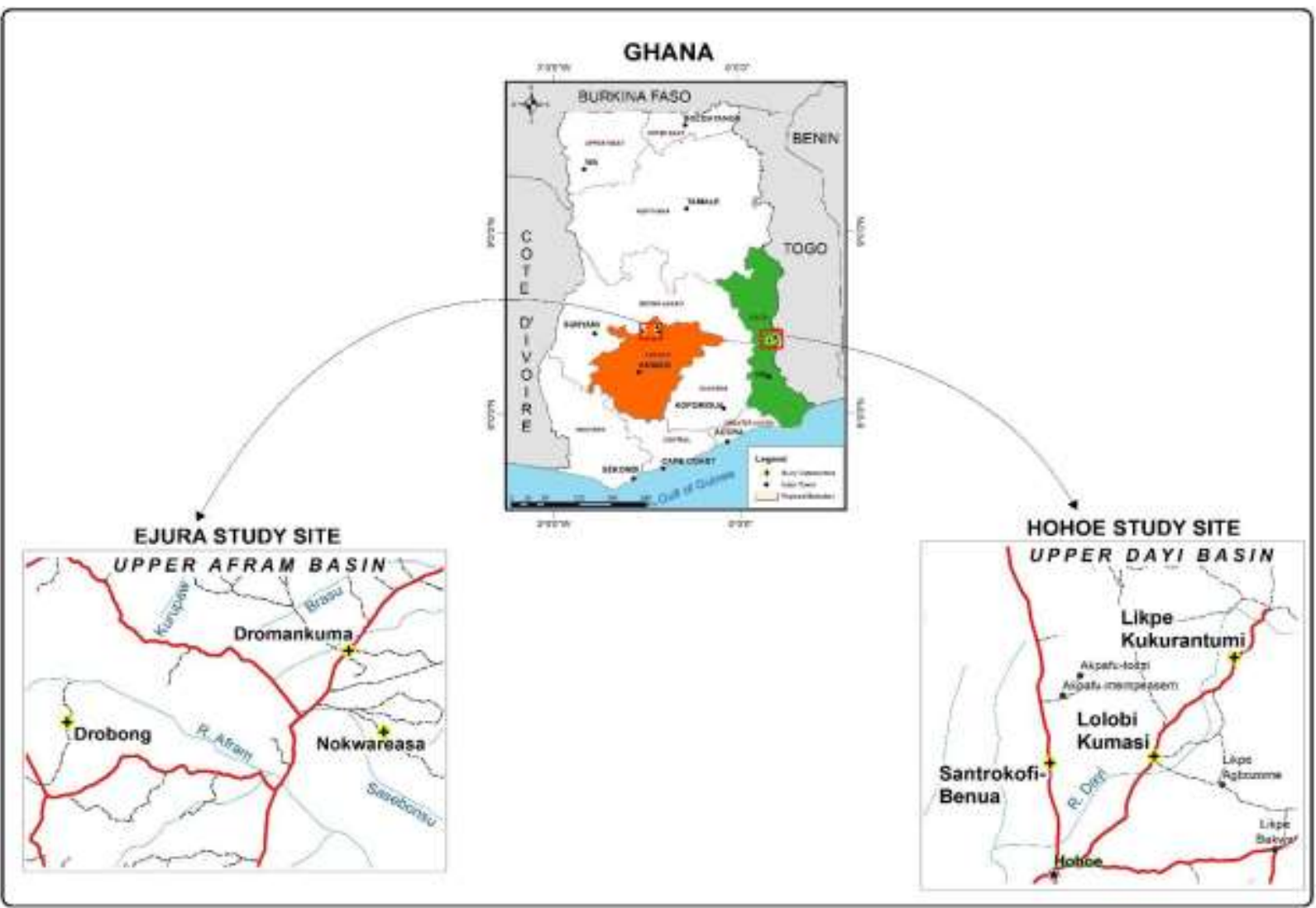

Figure 2.1. Map of Study areas showing the location of study communities

\section{Study communities}

Six (6) farming communities were selected from two agro-ecologically diverse areas within the middle belt of the country. The study communities in the Upper Afram basin include Nokwareasa, Dromankuman and Drobon (Figure 2.1). Nokwareasa is located between Latitude $7021^{\prime} 13^{\prime \prime} \mathrm{N}$ and $7021^{\prime} 23^{\prime \prime} \mathrm{N}$, and Longitude 1018 ' $13^{\prime \prime} \mathrm{W}$ and 1018 ' 22 "W within the middle part of Ejura in the Ashanti region. It is a mix community with inhabitants comprising mainly of indigenes and some settlers. Dromankuman is a settler community located between Latitude 7025 ' 10 " N and $7025^{\prime} 37^{\prime \prime} \mathrm{N}$, and Longitude $1019^{\prime} 43^{\prime \prime} \mathrm{W}$ and $1020^{\prime} 15^{\prime \prime} \mathrm{W}$ within the Upper Afram catchment. The community is dominated by settlers from the northern regions of the country who migrated into the area to explore economic opportunities mainly farming. Drobon is a typical Ashanti community located between Latitude 7022 ' 0.00 " $\mathrm{N}$ and 
$7022^{\prime} 13^{\prime \prime} \mathrm{N}$, and Longitude $1033^{\prime}$ 22'W and $1033^{\prime} 35^{\prime \prime} \mathrm{W}$ within the Afram catchment. The study communities in Upper Dayi basin comprised Likpe-Kukurantumi, Lolobi-Kumasi and Santrokofi-Benua (Figure 2.1). LikpeKukurantumi is located between Latitude $7^{0} 15^{\prime} 20^{\prime \prime} \mathrm{N}$ and $7^{0} 15^{\prime} 45^{\prime \prime} \mathrm{N}$, and Longitude $0^{0} 33^{\prime} 55^{\prime \prime} \mathrm{E}$ and $0^{0} 34^{\prime} 15^{\prime \prime}$ $\mathrm{E}$ in the Likpe traditional area in the Hohoe District of the Volta Region. The Likpe traditional area comprises twelve communities with inhabitants of diverse backgrounds. Lolobi-Kumasi is located between Latitude $7^{0} 12^{\prime} 20^{\prime \prime} \mathrm{N}$ and $7^{0} 12^{\prime} 50^{\prime \prime} \mathrm{N}$, and Longitude $0^{\circ} 31^{\prime} 20^{\prime \prime} \mathrm{E}$ and $0^{\circ} 31^{\prime} 45^{\prime \prime} \mathrm{E}$ at an elevation of $250 \mathrm{~m}$ above sea level. Inhabitants of the Lolobi and Akpafu originally were one ethnic group and therefore spoke the same language. Inhabitants are mainly rice and cocoa farmers. Santrokofi-Benua is one of the three communities in the Santrokofi traditional area in the Hohoe municipality. It is located between Latitude $7^{0} 12^{\prime} 10^{\prime \prime} \mathrm{N}$ and $7^{0} 12^{\prime} 35^{\prime \prime} \mathrm{N}$, and Longitude $0^{\circ} 28^{\prime} 15^{\prime \prime} \mathrm{E}$ and $0^{0}$ $28^{\prime} 35^{\prime \prime} \mathrm{E}$ and shares common boundaries with Akpafu to the north and Lolobi to the east. The inhabitants of this community are mainly farmers and hunters.

\subsection{Sampling, Data collection and Analysis}

Data was collected through On-the-Spot Observations; Key Informant Interviews; Focus Group Discussions; and Questionnaires. Two hundred and seventy-one (271) respondents comprising Farmers, Crop research scientists, Agricultural officers, and Farmer based Organizations were interviewed with the assistance of agricultural extension officers. Socio-economic characteristics of the respondents were also collected to help understand the unique backgrounds of respondents and how this influenced their responses. The respondents possessed the relevant traditional knowledge relating to indigenous crops and the general agricultural history of the study areas. During the focus group discussions and individual interviews respondents provided rich descriptions of the uses and benefits food crop varieties currently cultivated and the indigenous crops. The names and varieties of neglected and underutilized crops, as well as the reasons for their decreased use, in the study areas, were also given. The qualitative data were analyzed thematically and presented in descriptive forms. The data collected helped to generate an inventory of NUCS in the two study basins. The results were also presented in the form of frequencies, percentages and tables, using descriptive statistics.

\subsection{Results and discussions}

\subsection{Socio-economic background of respondents}

Majority of the communities within the Upper Afram and Upper Dayi basins consist mainly of agricultural households with similar agricultural history. For example, inhabitants of Likpe, one of the study communities in the Upper Dayi basin are known to have migrated alongside other Guan groups and settled in Atebubu in the Brong Ahafo Region in the Afram basin. These household are engaged primarily in agriculture, particularly crop farming. Inhabitants of the two basins also share some common farming practices and households acquired lands and owned farm plots through inheritance. Extensive practice of commercial agriculture with a high monoculture practices involving mainly maize production is practiced in most communities in the Upper Afram basin. Maize and yam constituted the main commercial food crops in the Upper Afram basin whilst the Upper Dayi basin is associated mainly with commercial cultivation of cocoa and rice. Most households therefore engaged in the sale of these crops as source of livelihood. The large-scale cultivation of cocoa however, resulted in the conversion of most arable farm lands for cocoa production at the expense of the cultivation of other food crops. Inhabitants from communities within the Upper Afram basin consist mainly of typical Asantes as well as settlers from the Northern regions of Ghana, whilst those of Upper Dayi are mainly indigenes. Marketing of farm produce in the study communities of the Upper Afram basin is well structured to safeguard the interest of food crop marketers. Most of them have constituted themselves into individual marketers and farmer-based associations such as the Yam Sellers Association, United Farmers Association, Kasapa Farmers Association and the Vegetable Growers Association. In the Upper 
Dayi basin Brown rice in particular is an important staple which is heavily patronized by the community members and traders.

\subsection{NUCS in the Upper Afram and Upper Dayi basins}

A total of one hundred and twelve (112) NUCS were identified during the study in the Upper Afram and Upper Dayi basins (Table 3.1). The NUCS identified were found within the food crop categories including cereals, legumes, vegetables, root and tubers, and trees and plantations. Eighty (80) NUCS were identified during the survey at the Upper Afram basin (Table 3.2). Out of the 80 NUCS identified, 14 were cereals, 13 were legumes, 5 were vegetables, 32 were root and tubers, and 16 were tree crops and fruits. Out of the 32 root and tubers, over twenty (20) yam species were recorded. Yam varieties that were previously cultivated but presently marginalized or no more cultivated in the Upper Afram basin include: Bayere Kwankwesi, Asobayere (hard with sweet taste), Ababayere, Apoka (big roundish), Anomesu, Nsuabayere, Densi (Esum ne Hyen), Nananto (good taste and flavour), Akaba, Krokropa (small and roundish), Latopa (hairy), Bole, Tampi, Kyikumasi, Atipe (yellowish), Ahonome (high yielding, smallish with sweet taste), Akam (Aerial Yam), Edunkra, Afase Kokoo, Natori, Nemos (strong good flavour), Saabri, Nkuku (roundish),

\section{Table 3.1: Inventory of NUCS in the two study basins}

\begin{tabular}{|c|c|c|c|}
\hline No & Food crop category & NUCS in Upper Afram basin & NUCS in Upper Dayi basin \\
\hline 1. & Cereal & $\begin{array}{l}\text { Maize sp. (Zea mays)- Dwarf, Baatampa, } \\
\text { Abrohama (long cob with lots of smaller } \\
\text { grains), Dobidi (white), Daduanan (yellow), } \\
\text { Laposta, Mamaba (white), Okomasa (white), } \\
\text { Abelehi (white), Debo } \\
\text { Millet (Pennisetum glaucum), Sorghum } \\
\text { (Sorgbum bicolor), Ekpe (kokomba language } \\
\text { - Fonio), Mokoko }\end{array}$ & $\begin{array}{l}\text { Indigenous brown rice (Oryza } \\
\text { glaberrima) } \\
\text { Rice sp. Twomavor, Mawnulukpu } \\
\text { Akuablue, Kable, Khaki, Akpese, } \\
\text { Mawutse, Tomayobi }\end{array}$ \\
\hline 2. & Legumes & $\begin{array}{l}\text { Bambara beans (Vigna subterranea), Agushi } \\
\text { (Citrullus colocynthis), Werewere (Citrullus } \\
\text { vulgaris), Beans - [varieties: Atidua (red } \\
\text { beans - Vigna sp.), Apatram (white; } \\
\text { Phaseolus vulgaris), Akye, Aduakuma } \\
\text { (coloured; Phaseolus sp.), Aduapia } \\
\text { (Phaseolus sp.), Adua daagati (Vigna sp.), } \\
\text { Pangabu (Vigna sp.) Forehead (Vigna sp., } \\
\text { whitish), Osei (Vigna sp., spotted)], red } \\
\text { groundnut (Arachis hypogaea). }\end{array}$ & $\begin{array}{l}\text { Bambara Beans (Vigna subterranea), } \\
\text { Apatram (Phaseolus sp.), Akeani, } \\
\text { Kakpe, Agushi (Citrullus colocynthis) }\end{array}$ \\
\hline 3. & Vegetables & $\begin{array}{l}\text { Efre (pumpkin, Cucurbita maxima), Misewa } \\
\text { (pepper, Capsicum anmum), Monsurowa (type } \\
\text { of garden eggs, Solanum sp.), Kwabu nsusua } \\
\text { (turkey berry, Solanum torvum), Cucumber } \\
\text { (Cucumis sativus) }\end{array}$ & $\begin{array}{l}\text { Shallots (Alium spp.), Misewa } \\
\text { (pepper, Capsicum anmum), Soro } \\
\text { wisa (African Black pepper), Bitter } \\
\text { leaves (Vernonia amygdalina), } \\
\text { Akpamkpele (small garden eggs, } \\
\text { Solanum spp.) }\end{array}$ \\
\hline 4. & Root $\&$ tubers & $\begin{array}{l}\text { Nkanfor (Dioscorea dumetorum), Cocoyam } \\
\text { (Xanthosoma spp), Taro (Colocasia esculenta), } \\
\text { Sweet potato (Ipomoea batatas), } \\
\text { Yam species: [ varieties: Bayere Kwankwesi, } \\
\text { Asobayere (hard with sweet taste), } \\
\text { Ababayere, Apoka (big roundish), Anomesu, } \\
\text { Nsuabayere, Densi (Esum ne Hyen), Nananto } \\
\text { (good taste and flavour), Akaba, Krokropa }\end{array}$ & $\begin{array}{l}\text { Nkanfo (Dioscorea dumetorom), Sweet } \\
\text { Potatoes (Ipomoea batatas), Taro } \\
\text { (Colocasia esculenta), } \\
\text { Yam varieties: Nakani, Oboaduanan, } \\
\text { Befosi, Seklorsi, Aerial yam, Kookoasi } \\
\text { bayere, Snake water yam }\end{array}$ \\
\hline
\end{tabular}




\begin{tabular}{|c|c|c|c|}
\hline & & $\begin{array}{l}\text { (small and roundish), Latopa (hairy), Bole, } \\
\text { Tampi, Kyikumasi, Atipe (yellowish), } \\
\text { Abonome (high yielding, smallish with } \\
\text { sweet taste), Akam (Aerial Yam), Edunkra, } \\
\text { Afase Kokoo, Natori, Nemos (strong good } \\
\text { flavour), Saabri, Nkuku (roundish), } \\
\text { Afasiemansa (water yam), Daatori, Anasu } \\
\text { (yellowish water yam), Tantanpruga, } \\
\text { Nankani (round, sweet taste) }\end{array}$ & \\
\hline 5. & $\begin{array}{c}\text { Tree crops/ } \\
\text { Plantation/Fruits }\end{array}$ & $\begin{array}{l}\text { Cocoa (Theobroma cocao), Pear (Pyrus spp.), } \\
\text { Alatakwadu (Musa spp.), Asantekwadu (Musa } \\
\text { spp.), Pineapple (Ananas comosus), } \\
\text { Sugarcane (Saccharum officinarum), Afre } \\
\text { (Types of Apple, Malus spp.), Water Melon } \\
\text { (Citrullus lanatus), Salo Mango (Mangifera } \\
\text { spp.), Dawadawa (Parkia biglobosa), Guava } \\
\text { (Psidium guajava), Atia (cashew, Anacardium } \\
\text { occidentale), Asua (Miracle Fruit, Synsepalum } \\
\text { dulcificum), Pawpaw (Carica papaya), Oniaba } \\
\text { (Type of Plantain, Musa spp.), Medom } \\
\text { (Type of Palm fruit, Elaeis spp.) }\end{array}$ & $\begin{array}{l}\text { Cashew (Anacardium occidentale), } \\
\text { coffee (Coffea sp.), Bebitoklotsa } \\
\text { (infant banana), Boaborfi (purplish } \\
\text { banana) }\end{array}$ \\
\hline
\end{tabular}

Afasiemansa (water yam), Daatori, Anasu (yellowish water yam), Tantanpruga, Nankani (round, sweet taste). The different tree crop species and plantations include Cocoa (Theobroma cocao), Pear (Pyrus spp.), Alatakwadu (Musa spp.), Asantekwadu (Musa spp.), Pineapple (Ananas comosus), Sugarcane (Saccharum officinarum), Afre (Type of Apple, Malus spp.), Water Melon (Citrullus lanatus), Salo Mango (Mangifera spp.), Dawadawa (Parkia biglobosa), Guava (Psidium guajava), Atia (cashew, Anacardium occidentale), Asua (Miracle Fruit, Synsepalum dulcificum), Pawpaw (Carica papaya), Oniaba (Type of Plantain, Musa spp.), and Medom (Type of Oil Palm, Elaeis spp.). The Upper Dayi basin on the other hand recorded a total of thirty-two (32) NUCS (Table 3.2). Out of the 32 NUCS identified, 8 were cereals, 5 were legumes, 5 were vegetables, 10 were root and tubers, and 4 were tree crops and plantations. The root and tubers recorded the highest number of marginalized crop species.

Table 3.2 NUCS in the two study basins

\begin{tabular}{lccc}
\hline Food crop category & $\begin{array}{c}\text { Upper Afram } \\
\text { basin }\end{array}$ & $\begin{array}{c}\text { Upper Dayi } \\
\text { basin }\end{array}$ & $\begin{array}{c}\text { Total number } \\
\text { of NUCS }\end{array}$ \\
\hline Cereals & 14 & 8 & 22 \\
Legumes & 13 & 5 & 18 \\
Vegetables & 5 & 5 & 10 \\
Root \&Tubers & 32 & 10 & 42 \\
Trees/Plantain/ Fruits & 16 & 4 & 20 \\
\hline Total & $\mathbf{8 0}$ & $\mathbf{3 2}$ & $\mathbf{1 1 2}$ \\
\hline
\end{tabular}

These include Nkanfo (Dioscorea dumetorom), Sweet Potatoes (Ipomoea batatas), Taro (Colocasia esculenta), and Yam varieties: Nakani, Oboaduanan, Befosi, Seklorsi, Aerial yam, Kookoasi bayere, and Snake water yam. This was followed by cereals: Indigenous brown rice (Oryza glaberrima) and other Rice species such as Twomavor, Mawulukpu Akuablue, Kable, Khaki, Akpese, Mawutse, and Tomayobi. Rice was found to be the commonly grown food crop among farmers in the 
study communities. The indigenous brown rice (Oryza glaberrima) which was a delicacy is currently marginalized and grown on a minimal scale, giving way for other improved varieties to be cultivated.

Pictures of some NUCS are presented in plates A to E.

Plate A: Cereals

[A1] Indigenous brown rice [A2] Millet; [A3] Sorghum

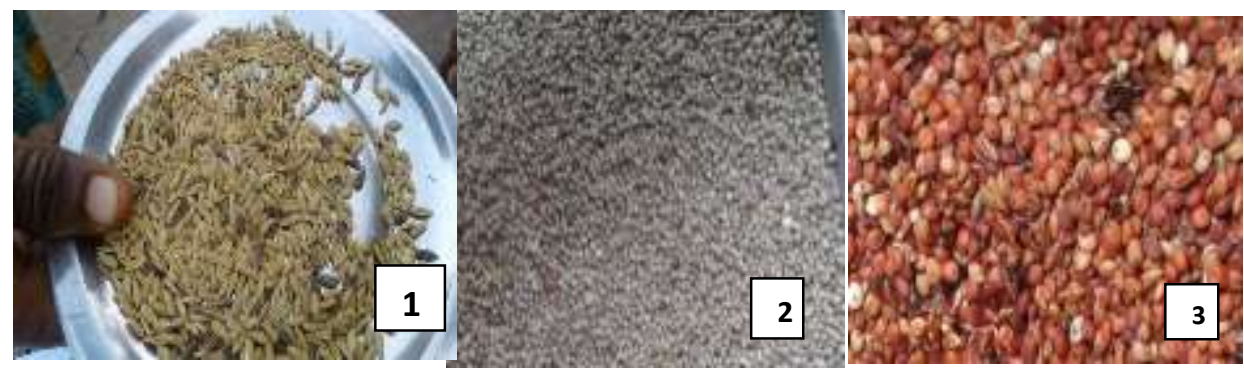


Plate B: Legumes

[B1] Soyabean

[B2] Red beans

[B3] Werewere

[B4] Kidney bean

B57 Apatram (Phaseolus)

[B6] White Apatram
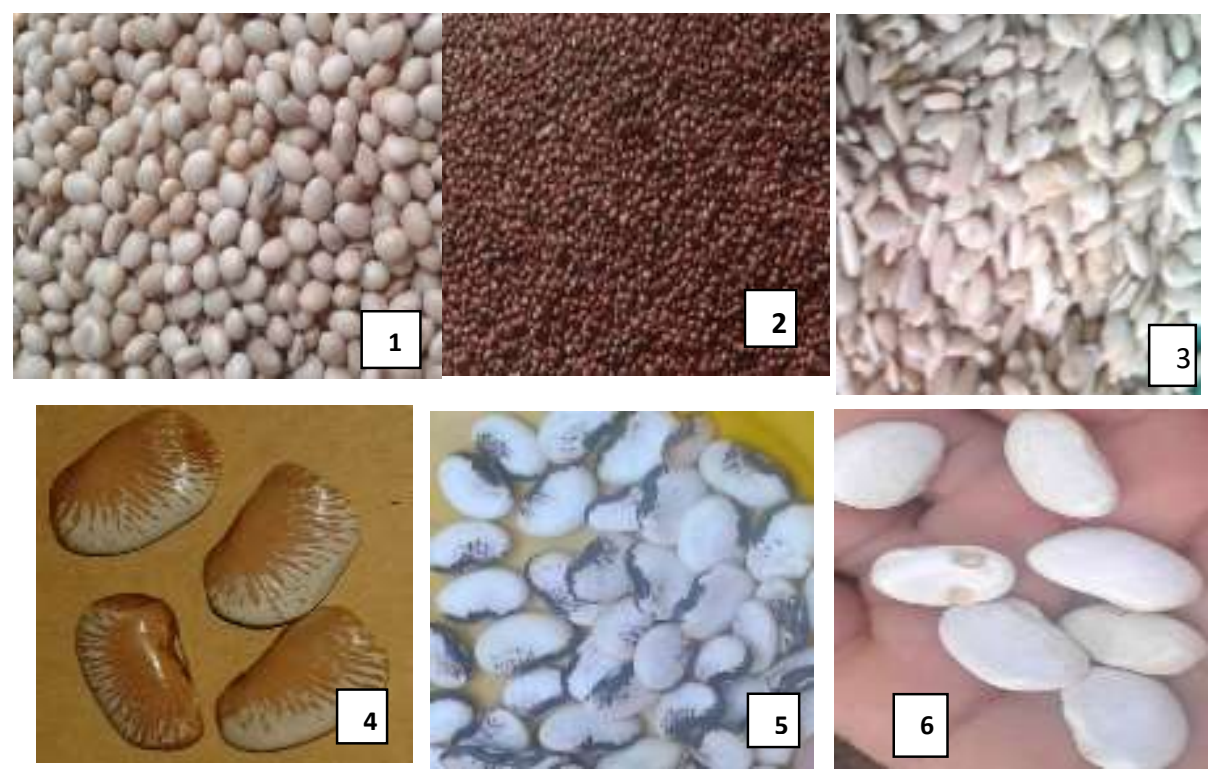

Plate C: Vegetables

[C1] Nsusua

[C2] Garden eggs- ntropo

[C3] Shallots

[C4] Cbili pepper
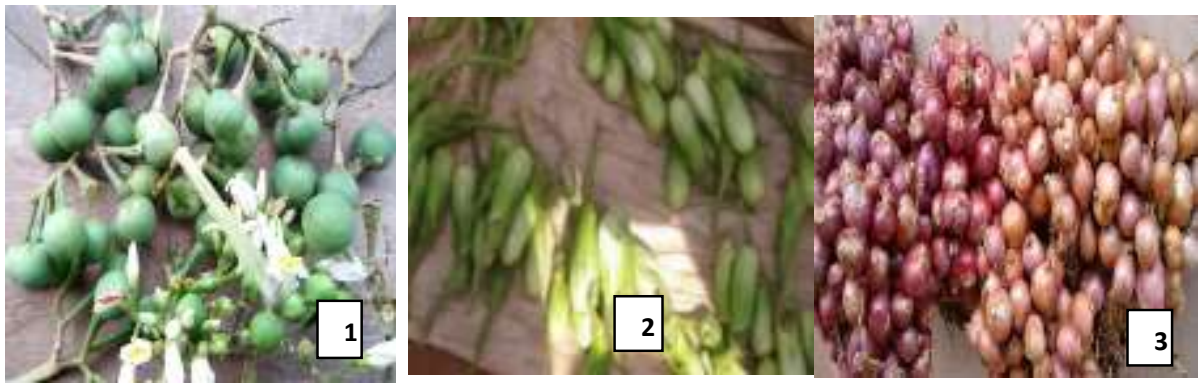

[C5] Nsusua

[C6] Borkorborkor
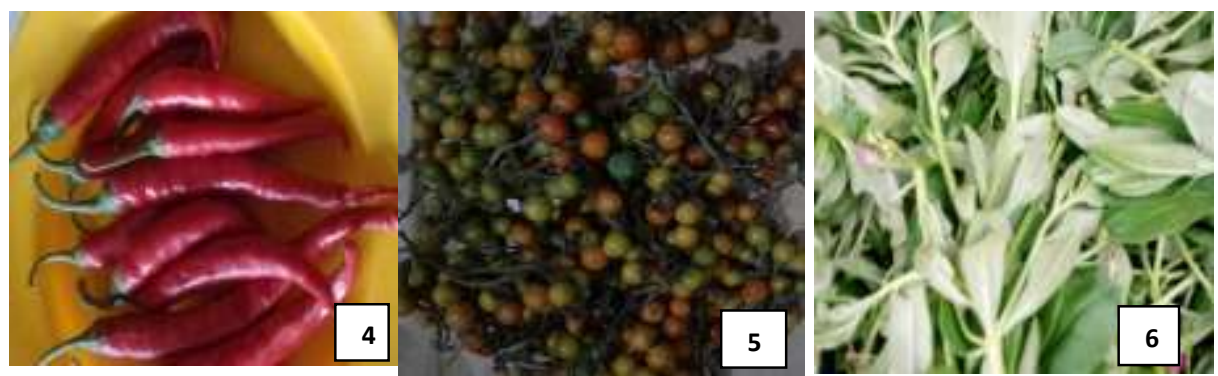
Plate D: Root \& tubers

[E1] Atretre (water yam)

[E2] Nkanfo

[E3] Aerial yam
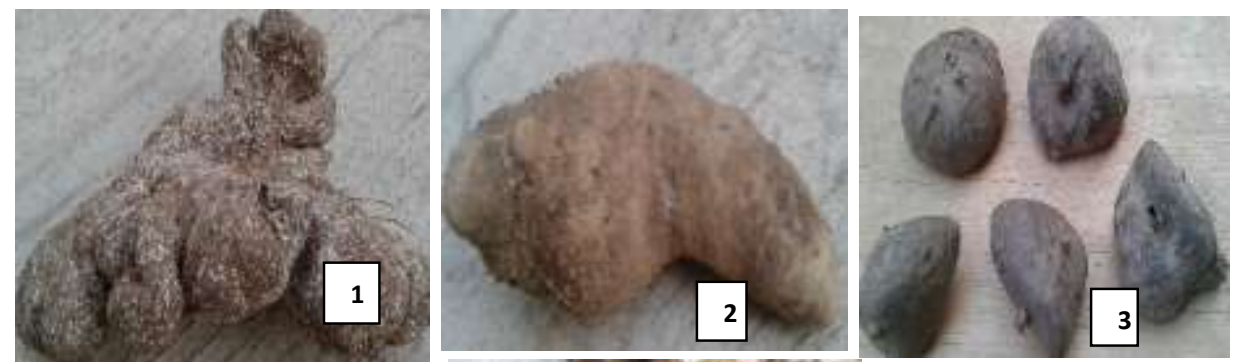

[E4] Densi

[E5] Taro

E6] Akaba
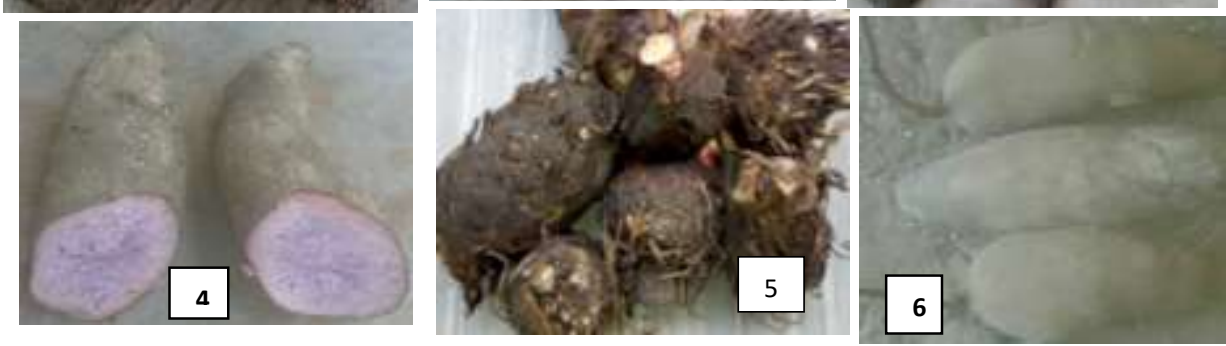

Plate E: Fruits/Plantation

[F1] Mango

[F2] Miracle berry
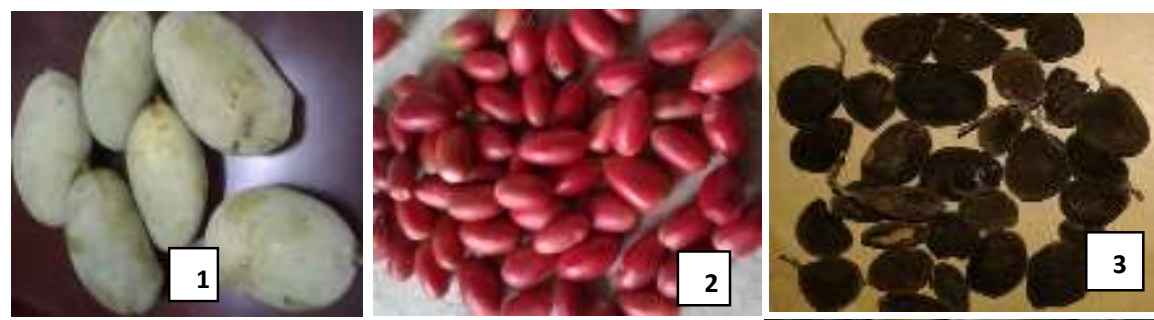

[F3] Tamarind

[F4] Plantain

[F5] Banana

[F6] Asanfron
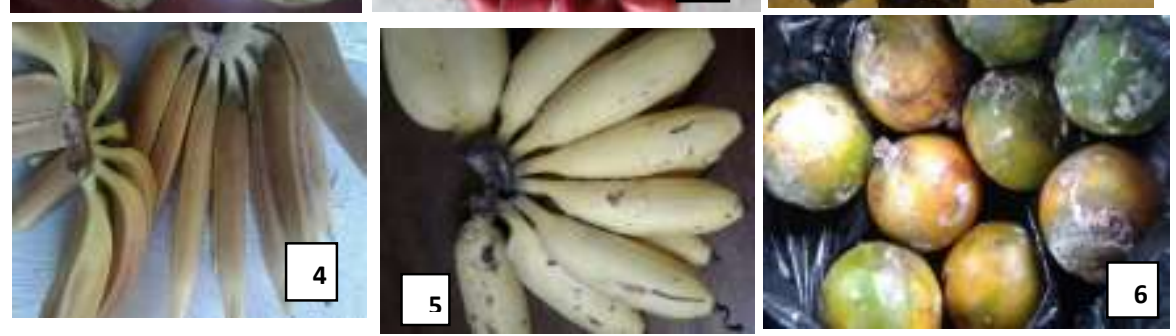

Neglected and Underutilized Crop Species (NUCS) constitute an integral part of agrobiodiversity and are known to occur widely in various forms both in temperate and tropical areas (Padulosi et al., 2013) including Ghana. Studies on agrobiodiversity and NUCS in Ghana have confirmed the diverse nature and usefulness of these crops in various parts of the country. The over hundred NUCS identified during the study is a confirmation of the existence of a valuable plant resource that can be effectively exploited to help address the food inadequacy challenges among rural households and farming communities within the Upper Afram and Upper Dayi basins. The Upper Afram and Upper Dayi basins are known to possess relatively rich agrodiversity accounting for the wide variety of food crops and plant species in the areas. The two river basins differ slightly in their ecological conditions. These unique characteristics were also reflected in the study findings as the Upper Afram basin recorded relatively higher numbers of NUCS compared to the Upper Dayi basin. The observed NUCS diversity found within the two study basins could be attributed to the rich agrobiodiversity of the semi-deciduous rainforest and the forest savannah transition zones within which the study was carried out. This rich diversity has also been reported by Nyadanu et al. (2015) who examined the NUCS diversity among other things in some selected farming towns located within the coastal, forest, 
transitional and guinea savanna zones of Ghana. The high numbers of NUCS identified presents the agricultural sector with the opportunity to consider widening the national food basket to include NUCS especially given their known contribution to food security among indigenous communities. The NUCS inventory survey further shows that several species of indigenous food crop varieties in central Ghana are currently under cultivated, marginalized and neglected due to some identifiable causes. The marginalization and subsequent erosion of over twenty yam species recorded during the study is a source of concern as yam is a commonly cultivated food crop in the area. This incidence of serious genetic erosion of yams is also corroborated by (Aboagye et al., 2015). Yam is regarded as one of the few important staple crops in Ghana. It plays an important role in the cultural rites (such as yam festivals) of the people of Ghana. Yam also referred to as "King of Crops" in Nigeria, contributes substantially to household food security (Kenyon \& Fowler, 2000). Yam is also known to provide a wide variety of dishes that are boiled, roasted or fried. Depending on the variety, it could be used for ampesi (boiled starchy staple served with stew or sauce), st (mashed yam), fufu (pounded yam), yam balls, porridge or fried yam chips. The erosion of yam varieties therefore may lead to loss of cultural identity of some tribal groups, change of favourite staples, among others. Several indigenous varieties of some of Ghana's key staple crops such as yam and rice were no more cultivated and on the verge of extinction.

\subsection{Uses and benefits}

Responses gathered from interviews during the study revealed that the NUCS provided several benefits and played important roles in traditional ceremonies. They also served as feed for livestock, dyes, fodder, medicinal, fuel wood, nutritional, food, soap, among others. Concerning the method of preparation and the parts of the crop or plant (NUCS) used, the respondents in both study basins pointed out various methods including boiling, roasting and frying. According to them the commonly used parts include the seeds, leaves, stalk, fruits, roots and tubers (Table 3.3). On the consumption pattern and preference for the marginalized crop varieties among different age groups, it was found that consumption was high (98\%) among both males and females even though it was also indicated that the preference and consumption of some of these indigenous crops among current younger generation is generally low perhaps due to the lack of knowledge of these crops and their nutritional benefits. In Upper Afram for example, $A$ kye, a brownish coloured bean (Vigna spp.), was known for its nutritious and pleasant taste, as well as its ability to sustain and satisfy one's hunger for a long period. A farmer at Drobon said " $A$ kye, it will stay on you for long time when you eat and it is heavy". The leaves of some bean's species were also used for soup preparation and the liquid obtained from cooking the leaves used for medicinal purposes. Phaseolus sp. (lima beans or locally called 'Apatram') for example, was used mainly for soup preparation. This was patronized by pregnant women mainly due to their belief in its ability to facilitate easy labour or delivery. Pawpaw leaves and pineapple (fruit and peels) and at times in combination with other herbs were used for medicinal purposes, especially in eliminating or curing feverish conditions. Pumpkin, locally referred to as 'Efre' was also considered to possess some medicinal properties. Millet was also found to have several uses. Millet grains, apart from being used for porridge, a breakfast meal and other meal preparation, were also used in the preparation of an alcoholic drink called 'pito'. As one farmer from Dromankoman puts it, "Millet gives difference to our food". The millet stalk also served as feed for their livestock, source of cook fuel and was also used for traditional mat weaving. Yams traditionally also served as a major item in gift packages for respected people in the communities. Kwabu nsusuaa and Monsorowa (also called nsusuaa), apart from being very nutritious also served as a remedy for managing cases of anaemia. In the Upper Dayi basin indigenous brown rice, referred to as 'Kamortintin' was found to be a delicacy even though it was marginalized. A respondent at Likpe, said "Kamortintin is good, is sweet, it begins to be big and swell when you cook, it takes water, then it becomes plenty". According to the farmers, the water that remains after the rice has boiled for some time is scooped and used as a form of Orally Rehydrated Salt (ORS) for the sick. Indigenous brown rice is also presumed to be good for 
diabetes. Table 3.4 gives the nutritional composition of selected traditional and exotic vegetables from Nyadanu and Lower's studies, which also corroborates the high nutritional content of indigenous crops.

Table 3.4: Nutrient composition per 100g Fresh edible portion of selected traditional vegetables compared with exotic vegetables

\begin{tabular}{lcccccc}
\hline & $\begin{array}{l}\text { Amaranthus } \\
\text { sp. } \\
\text { (Aleefu) }\end{array}$ & $\begin{array}{l}\text { C. olitotorius } \\
\text { (Ademe) }\end{array}$ & $\begin{array}{l}\text { Cocoyam } \\
\text { leaves }\end{array}$ & $\begin{array}{l}\text { S. } \\
\text { torvum }\end{array}$ & Lettuce & Cabbage \\
\hline Carbohydrate (g) & 12.13 & 19.56 & 15.63 & 7.50 & 2.79 & 5.8 \\
\hline Energy (kcal) & 49.89 & 56.78 & 38.48 & 43.7 & 15 & 25 \\
\hline Fibre (g) & 1.78 & 1.61 & 3.34 & 5.40 & 1.3 & 2.5 \\
\hline Protein (g) & 9.41 & 5.42 & 11.61 & 2.20 & 1.36 & 1.3 \\
\hline Fat (g) & 0.35 & 0.43 & 0.71 & 0.76 & 0.15 & 0.1 \\
\hline Vit C (mg) & 3.86 & 14.56 & 2.58 & 112.60 & 9.2 & 36.6 \\
\hline Vit A (IU) & 2149 & 3214 & 3116 & 4172 & 7405 & 98 \\
\hline Iron (mg) & 45.41 & 19.53 & 15.92 & 10.6 & 0.86 & 0.47 \\
\hline Calcium (mg) & 252.1 & 276.4 & 196 & 59 & 36 & 40 \\
\hline Phosphorus (mg) & 81.55 & 66.68 & 79.22 & 67.39 & 29 & 26 \\
\hline Potassium (mg) & 348.18 & 481.15 & 285.66 & 399.73 & 194 & 170 \\
\hline
\end{tabular}

Source: Nyadanu and Lower (2014)

Other studies from researchers such as Muhammad (2014) and Padulosi et al. (2013) have emphasized the nutritional composition of many leguminous crops which are known to contain high levels of protein and minerals. Findings of this study showed that some varieties of leguminous crops such as Bambara beans (Vigna subterranea), Agushi (Citrullus colocynthis) and Phaseolus sp. which also contain these important nutrients are also under-cultivated and marginalised.
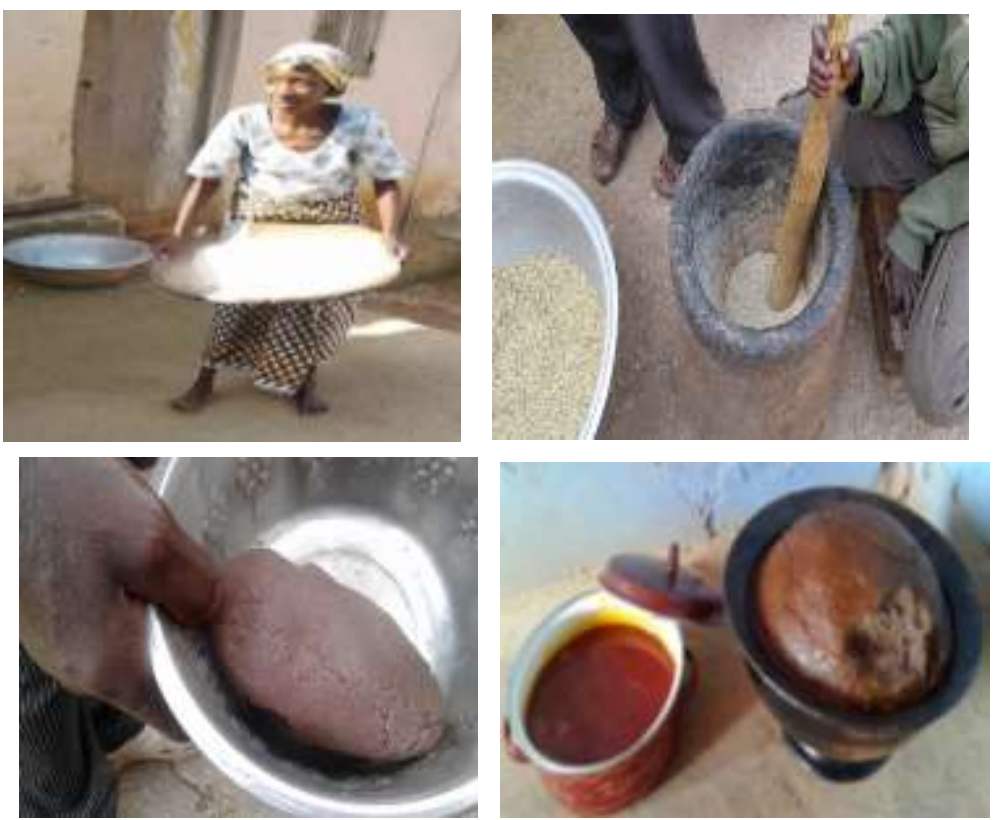

Plate F: Typical processing and use of Oryza glaberrima (indigenous brown rice) currently marginalized at Likpe and Lolobi 
A common feature among all the three study communities within the Upper Dayi basin is the use of the indigenous brown rice in the performance of some cultural practices especially in funerals and marriage ceremonies; and other activities including outdooring and installation of chiefs. In Lolobi, this indigenous brown rice is roasted, milled and prepared into a local delicacy called Kamorkra (Plate F). This is also called Kpakusi at Likpe. This traditional delicacy is usually expected to be prepared by the groom and sent to his in-laws. This meal is served with a special stew prepared with Kakpe (local climbing beans). Bitter leaves, locally called Segbe in Lolobi, is an NUCS that has several medicinal uses. Nsusua (Solanum spp.), misewa (pepper), esorowisa (African black pepper) and ginger are also believed to possess both nutritional and medicinal properties that help to manage some health conditions such as fever and stomach upsets. Other marginalized fruits mentioned and also deemed important by the farmers included some species of banana, known as 'Oklocha' and 'Kokote'. In Likpe 'Oklocha' was processed into a porridge-like food after boiling and mashed with a local sponge for smoothness, in a calabash. This was used to feed infants and babies and this made them grow very healthily. The people of Santrokofie also fed their babies on local bananas for their nutritional and health benefits. The 'Oklocha' banana species is also believed to contain some medicinal properties that help people suffering from piles. Another banana specie, 'Kokote' (Likpe), which is violet in colour was used in place of plantain in 'fufu' preparation; and also, a traditional delicacy called 'akankye'. Many NUCS have served as dietary support to many rural households and communities (Chivenge et al., 2015). The findings also revealed that some indigenous rice species in the Upper Dayi basin are currently underutilized and neglected. This observation could have adverse implications as rice was found to be the commonly grown food crop among farmers in the study communities. Additionally, rice is also regarded as one of the country's key staple crops. Asante et al., (2013) confirms that in recent years, rice has become an important staple food in Ghana. Rice is easy to cook and gives options for a wide variety of dishes. It possesses both nutritional and medicinal properties such as protecting the body against constipation (Olembo, M'mboyi \& Oyugi, 2010). Indigenous rice is also known for its socio-cultural values as it plays a major role in religious rites, festivals and other ceremonies such as wedding rites for the people of Likpe and Lolobi of Upper Dayi basin. It is also used for preparing baby foods, soups and brewing purposes (Olembo, M'mboyi \& Oyugi, 2010). The findings further showed that NUCS were used as source of food, medicine, dye and soap making, fuel wood, livestock feed among others in the study areas. The performance of some traditional ceremonies and activities such as the outdooring and installation of chiefs, funerals, marriage ceremonies in study communities in the Upper Afram and Upper Dayi basins are associated with NUCS. This is corroborated by IPGRI (2002) and Padulosi et al., (2013) who assert that NUCS represents an intimate part of local cultures and traditions. Table 3.3: Profile of some NUCS is provided below. 


\begin{tabular}{|c|c|c|c|c|c|c|}
\hline Scientific name & Common name & Local name & Life form & Part(s) used & Purpose & Method of preparation \\
\hline \multicolumn{7}{|l|}{ A. Cereals } \\
\hline 1. Zea mays & Maize & Abro & Grass & Seeds/leaves & $\begin{array}{l}\text { Food/fodder/ feed } \\
\text { livestock }\end{array}$ & Boiling/roasting \\
\hline 2. Pennisetum glaucum & Millet & Aуио & Grass & Seed/leaves \& stalk & $\begin{array}{c}\text { Food/drink/mat/ feed } \\
\text { livestock/ basket }\end{array}$ & Boiling/roasting \\
\hline 3. Sorghum bicolour & Sorghum & & Grass & Seed/leaves \& stalk & $\begin{array}{c}\text { Food/fuelwood/feed } \\
\text { livestock/dye }\end{array}$ & Boiling/roasting \\
\hline 4. Oryza glaberrima & Ind. Brown rice & Kamor & Grass & Seed & $\begin{array}{c}\text { Food/traditional } \\
\text { ceremonies }\end{array}$ & Boiling/roasting \\
\hline \multicolumn{7}{|l|}{ B. Legumes } \\
\hline 1. Vigna subterranean & Bambara beans & Akyin & Herb & Seeds & Food & Boiling/roasting \\
\hline 2. Citrullus colocynthis & Egushi/Agushi & Egushi & Climber & Seeds & food/ stew/ sauce & stewing \\
\hline 3. Citrullus vulgaris & Werewere/ neri & Werewere & Climber & Seeds & food/soup & boiling/roasting \\
\hline 4. Vigna unguiculata & Red beans & Atidua & Herb & seeds/leaves & food/stew & boiling \\
\hline 5. Phaseolus vulgaris & Limma & Apatram & Climber & Seeds & food/soup & boiling \\
\hline 6. Vigna spp. & Brown beans & Akye & Herb & Seeds & Food & boiling \\
\hline 7. Arachis bypogeal & Groundnut (red) & katekokoo & Herb & Seeds & Food & boiling/roasting/frying \\
\hline \multicolumn{7}{|l|}{ C. Vegetables } \\
\hline 1. Cucurbita maxima & Pumpkin & Efre & Climber/Vine & fruit/seeds/leaves & food/medicinal & raw/boiling/stewing \\
\hline 2. Capsicum anmum & Small Pepper & Misewa & Shrub & Fruit & food/nutritional/medicinal & raw/boiling \\
\hline 3. Solanum sp. & Small garden eggs & $\begin{array}{c}\text { Monsurowal } \\
\text { nsusuaa }\end{array}$ & Shrub & Fruit & food/nutritional/medicinal & Boiling \\
\hline 4. Cucumis sativus & Cucumber & & Climber/Vine & Fruit & food/nutritional & raw/boiling \\
\hline 5. Solanum torvum & Turkey berry & Kwahu nsusua & Shrub & fruit \& leaves & food/ nutritional/medicinal & raw/boiling \\
\hline \multicolumn{7}{|c|}{ D. Roots and tubers } \\
\hline 1. Dioscorea dumetorum & Yam sp. & Nkanfor & Climber/Vine & Roots/tubers & Food & Boiled with skin on \\
\hline 2. Xanthosoma spp. & Cocoyam & Mankani & Herb & Roots/tubers/leaves & $\begin{array}{l}\text { food/ feed poutry/ } \\
\text { stew/soup }\end{array}$ & Boiling/roasting/frying \\
\hline 3. Colocasia esculenta & Taro & Brobe & Herb & Roots/tubers/leaves & food/ stew/ feed poultry & Boiling/roasting/frying \\
\hline 4. Ipomoea batatas & Sweet potato & Ntromo & Climber/Vine & Roots/tubers/leaves & food/feed livestock & Boiling/ roasting/frying \\
\hline 5. Dioscorea $s p$ & Yam species & Bayere & Climber/Vine & Roots/tubers & Food & Boiling/roasting/frying \\
\hline
\end{tabular}




\begin{tabular}{|c|c|c|c|c|c|c|}
\hline $\begin{array}{l}\text { E. Tree crops/ } \\
\text { Plantations }\end{array}$ & & & & & & \\
\hline 1. Theobroma cocao & Cocoa & Cocoa & Tree & Fruit/seed & Food & $\begin{array}{l}\text { Raw/ Industrial } \\
\text { processed }\end{array}$ \\
\hline 2. Pyrus spp. & Pear & Paya & Tree & Fruit & Food & Raw \\
\hline 3. Musa spp. & Banana & Alatakwadu & Shrub & Fruit & Food & Raw \\
\hline 4. Musa spp. & Local Banana & Asantekwadu & Shrub & Fruit & Food & $\begin{array}{l}\text { Raw/boiled in some } \\
\text { cases }\end{array}$ \\
\hline 5. Ananas comosus & Pineapple & Abrobe & Shrub & Fruit/fruit peels & food/medicinal & Raw/peels boiled \\
\hline 6. Saccharum officinarum & Sugarcane & Ahwedes & Tree & Fruit & food/medicinal & Raw/Ind. Processed \\
\hline 7. Malus spp. & Type of apple & Afre & Shrub & Fruit & Food & Raw \\
\hline 8. Mangifera indica & Salo mango & Gyapha & Tree & fruit/bark/leaves & food/medicinal & $\begin{array}{c}\text { Raw/ bark \& leaves } \\
\text { boiled }\end{array}$ \\
\hline 9. Citrullus lanatus & Water melon & & Vine/Climber & Fruit & food/nutritional & Raw \\
\hline 10. Parkia biglobosa & Dawadawa & Dawadawa & Tree & fruit/seed & food/nutritional/medicinal & raw/seeds cooked \\
\hline 11. Psidium guajava & Guava & Agewa & Tree & fruit/leaves & food/medicinal & Raw \\
\hline 12. Anacardium occidentale & Cashew & Atia & Tree & fruit/seed & food/snack & Raw/roasted \\
\hline 13. Synsepalum dulcificum & Miracle fruit & Asua & Shrub & Fruit & Food & Raw \\
\hline 14. Carica papaya & Pawpaw & Brofre & Shrub & fruit/leaves & food/medicinal & Raw/ leaves boiled \\
\hline 15. Musa paradisiacal & Type of plantain & Oniaba & Shrub & Fruit & Food & Boiling/ frying/roasting \\
\hline 16. Elaeis guineensis & Type of oil palm & Medom & Tree & Fruit & food/oil/soap & Boiling \\
\hline
\end{tabular}




\section{Conclusion}

The study revealed that several varieties and species of indigenous food crops are presently being marginalized and underutilized with some species on the verge of complete erosion. The diversity of NUCS in the Upper Afram and Upper Dayi basins provides useful information and basis for the need to further explore the potential of other agro ecologically diverse areas of the country with the view to generating a national comprehensive inventory of these important but apparently overlooked food crop varieties. The study further established the important use of these food crops among the rural households and communities within the study basins. These findings demonstrate the untapped potential of NUCS particularly in the middle belt of the country. Finally, the study recommends that the relevant Ministries, Department and Agencies (MDAs) such as the Local Government, Ministry of Tourism, Arts and Culture, Ghana Tourism Authority, among others, to institute regular indigenous food fairs at the local (village), district and regional levels, in order to promote local dishes which are prepared from these indigenous food crops. Increased NUCS related studies particularly in the relevant public research institutions such as the Crops Research Institute and the Plant Genetic Resource and Research Institute of the Council for Scientific and Industrial Research, as well as the private sectors, will be critical to the effective promotion of these important local food crops.

\section{Acknowledgement}

The authors wish to express their gratitude to the Institute for Environment and Sanitation Studies (IESS) and the Management and Staff of Koforidua Technical University for their support. Also grateful to Mr. L. M. Aboagye from the Plant Genetic Resource and Research Institute-CSIR, Bunso in the Eastern Region of Ghana and Mr Emmanuel Addo, an agricultural extension officer from the Ministry of Food and Agriculture at Ejura in the Ashanti Region of Ghana. The views expressed are the authors' and do not necessarily reflect those of the institutions to which they are affiliated to.

\section{References}

1. Azam-Ali, S. N. (2010). Fitting underutilised crops within research-poor environments: Lessons and approaches. South African Journal of Plant and Soil, 27(4), 293-298.

2. Aboagye, L. M., Obirih-Opareh, N., Amissah, L., \& Adu-Dapaah, H. (2007). Analysis of existing national policies and legislation that enable or inbibit the wider use of underutilized plant species for food and agriculture in Ghana. Report. Ghana: Council for Scientific and Industrial Research.

3. Aboagye, L. M., Amoatey, H.M., Asante, I.K., Obiri-Opareh, N. \& Ofosu, I.W (2010). Ghana Country Report on Neglected and Underutilized Species. Report, Accra.

4. Aboagye, L. M., Nyadanu, D., Opoku-Agyeman, M. O., Owusu, S. K. \& Asiedu-Darko, E. (2015). Survey of diversity and production of yams in four comunities in Southern Ghana. African Journal of Agricultural Research, 10 (24): 2453-2459.

5. Asante, M. D., Asante, B. O., Acheampong, G. K., Offei, S. K., Gracen, V., Adu-Dapaah., H \& Danquah, E. Y. (2013). Farmer and consumer preferences for rice in the Ashanti region of Ghana: Implications for Rice breeding in West Africa. Journal of Plant Breeding and Crop Science, 5 (12): 229-238.

6. Bala Ravi, S. I Hoeschle-Zeledon, M. S. Swaminathan and E. Frison (eds) (2006). Hunger and Poverty: The Role of Biodiversity, MS Swaminathan Research Foundation and IPGRI, India and Rome, 232p.

7. Bhattacharjee, R. (2009). Harnessing Biotechnology for Conservation and Increased utilization of Orphan Crops. African Technology Development Forum Journal 6, Issue 3/4.

8. Chivenge, P., Mabhaudhi, T., Modi, A. T., \& Mafongoya, P. (2015). The potential role of neglected and underutilized crop species as future crops under water scarce conditions in Sub-Saharan Africa. International Journal of Environmental Research and Public Health, 12(6), 5685-5711.

9. FAO (2010). Second report on the state of the world's plant genetic resources for food and agriculture. Rome, Italy: Commission on Genetic Resources and Agriculture, FAO.

10. International Plant Genetic Resources Institute (IPGRI). (2002). Neglected and underutilized plant species: Strategic action plan of the International Plant Genetic Resources Institute. Rome: IPGRI.

11. Kenyon, L and Fowler, M, (2000). Factors affecting the uptake and adoption of output of crop protection 
research on yams in Ghana. Unpublished Paper, Natural Resource International Limited, UK.

12. Laker, M. (2007). Introduction to the special edition of Water SA on indigenous crops, water and human nutrition. Water SA 33 (3) http://www.wrc.org.za.

13. Modi, M., Modi, A., \& Hendriks, S. (2006). Potential role for wild vegetables in household food security: A preliminary case study in KwaZulu-Natal, South. Africa. Afr. J. Food Agric.Nutr. Dev. 6, 1-13.

14. Mabhaudhi, T., Modi, A.T., and Beletse, Y.G. (2011). Growth response of selected taro [Colocasia esculenta (L.) schott] landraces to water stress. In ISHS Acta Horticulturae 979: II International Symposium on Underutilized Plant. Species: Crops for the Future-Beyond Food Security; ISHS (International Society for Horticultural Science): Leuven, Belgium.

15. Mengistu, F \& Hager, H. (2008). Wild edible fruit species cultural domain, informant species competence and preference in three Districts of Amhara Region, Ethiopia. Ethnobotany Research \& Applications 6, 487-502.

16. Muhammad, Y. Y. (2014) Exploring the potential of bambara groundnut, an underutilized African legume species, towards food security in Africa. African Journal of Agricultural Science and Technology (AJAST), 2 (11): 201204.

17. Nyadanu, D. and Lowor, S. T. (2014). Promoting competitiveness of neglected and underutilized crop species: comparative analysis of nutritional composition of indigenous and exotic leafy and fruit vegetables in Ghana. Genet Resour Crop Evol, 61(6).

18. Nyadanu, D., Aboagye, L. M., Akromah, R. and Dansi, A. (2015). Agro-biodiversity and challenges of on-farm conservation: the case of plant genetic resources of neglected and underutilized crop species in Ghana. Genet Resour Crop Evol. DOI 10.1007/s10722-015-0327-2.

19. Nyadanu, D., Aboagye, L. M., and Ahamadou, B. (2014a) Managing risks and uncertainties in agriculture: the role of plant genetic resources of neglected and underutilized crop species in Africa. Book of Abstracts pp 26-

27. ANAFE symposium on agribusiness development and managing risk and uncertainties in African agriculture: the role of tertiary agricultural education, Yaounde.

20. Nyadanu, D., Mudita II, Gatachew, A. D, \& Bocar, A (2014b). Crop breeding for agriculture risk management. In: Agricultural risk management. Afr Agron.

21. Nyadanu, D. and Aboagye, L. M. (2014). Harnessing plant genetic resources of neglected and underutilized species for nutrition, food security and health in Africa. Book of abstracts, international research initiatives conference.

22. Olembo N, M'mboyi, F \& Oyugi, K. (2010). Success Stories in Crop Improvement in Africa. The Case of Rice in Sub-Saharan Africa. African Biotechnology Stakeholders Forum (ABSF). Nairobi, Kenya.

23. Padulosi, S., Thompson, J., \& Rudebjer, P. (2013). Fighting poverty, bunger and malnutrition with neglected and underutilized species: Needs, challenges and the way forward: Neglected and underutilized species. Rome, Italy: Biodiversity International.

24. Padulosi S. and Hoeschle-Zeledon I. (2004). Underutilized plant species: what are they? LEIS A Magazine, 20 (1): 5-6.

25. Padulosi, S., Hoeschle-Zeledon, I. \& Bordoni, P. (2008). Minor crops and underutilized species: lessons and prospects. In: N Maxted, BV Ford-Lloyd, SP Kell, JM Iriondo, MEDulloo, and J Turok (eds) CropWild Relatives Conservation and Use, pp. 605-624 CAB, International, Wallingford, UK.

26. Sprent, J. I., Odee, D. W., Dakora, F. D. (2009). African legumes: a vital but under-utilized resource. Journal of Experimental Botany, 61 (5): 1257-1265 